\title{
ARCH ve GARCH Modelleriyle Standard \& Poors 500 Endeksinde Rassal Yürüyüş ve Piyasa Etkinliğinin Analizi \\ Analysis of Random Walk and Market Efficiency in Standard \& Poors 500 Index Using ARCH and GARCH Models
}

\section{Nurgün KOMŞUOĞLU YILMAZ ${ }^{D}{ }_{a}$}

a İstanbul Aydın Üniversitesi, İktisadi ve İdari Bilimler Fakültesi, İstanbul, Türkiye, nurgunyilmaz@aydin.edu.tr

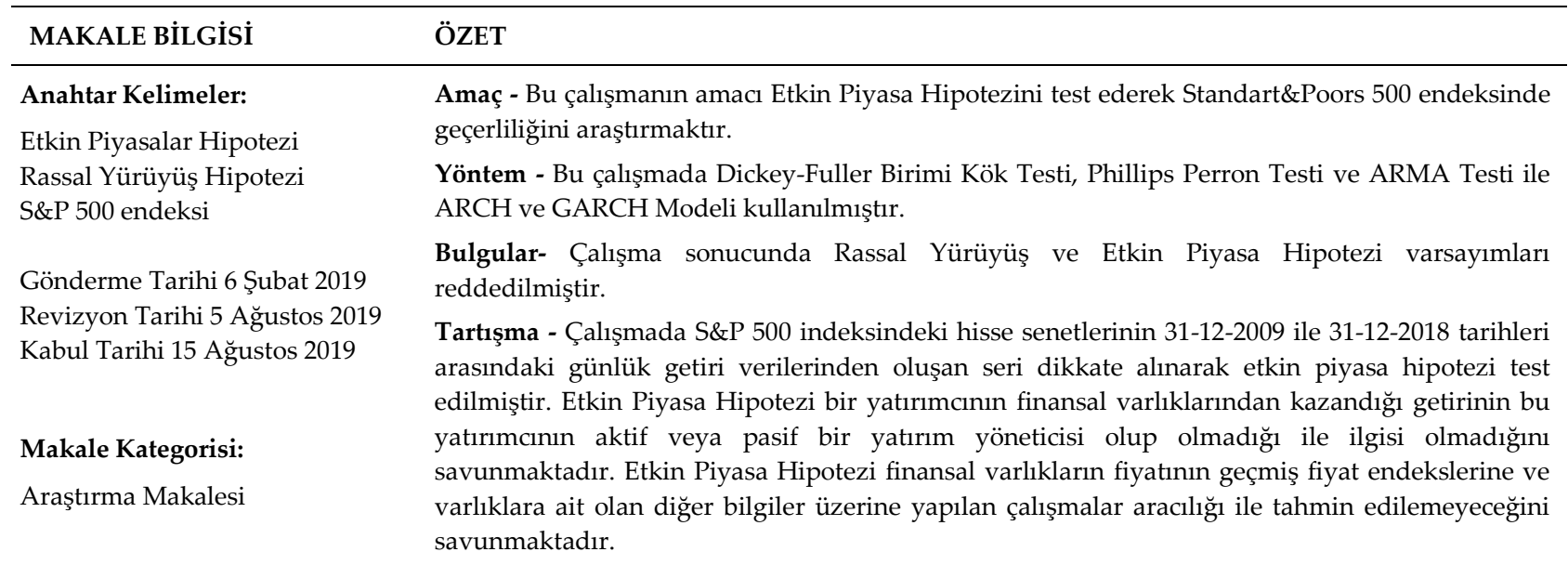

\begin{tabular}{|c|c|}
\hline ARTICLE INFO & ABSTRACT \\
\hline $\begin{array}{l}\text { Keywords: } \\
\text { Efficient Ma }\end{array}$ & $\begin{array}{l}\text { Purpose - The aim of this study is to test the Efficient Market Hypothesis and to show its validity } \\
\text { in Standard \& Poors } 500 \text { index. }\end{array}$ \\
\hline $\begin{array}{l}\text { Random Walk Hypothesis } \\
\text { S\&P } 500 \text { Index }\end{array}$ & $\begin{array}{l}\text { Design/Methodology/Approach - Dickey-Fuller Unit Root Test, Phillips Perron Test and ARMA } \\
\text { Test and ARCH and GARCH Model were used in this study. }\end{array}$ \\
\hline Received 6 February 2019 & $\begin{array}{l}\text { Findings - As a result of the study, assumptions of both random walk hypothesis and Efficient } \\
\text { Market Hypothesis are rejected. }\end{array}$ \\
\hline $\begin{array}{l}\text { Revised } 5 \text { August } 2019 \\
\text { Accepted } 15 \text { August } 2019\end{array}$ & $\begin{array}{l}\text { Discussion - The efficient market hypothesis was tested by taking into consideration the series of } \\
\text { daily yield data date between 31-12-2009 and 31-12-2018 of the shares of the S \& P } 500 \text { index. The } \\
\text { Efficient Market Hypothesis argues that an investor's return on its financial asset is not dealing }\end{array}$ \\
\hline $\begin{array}{l}\text { Article Classification: } \\
\text { Research Article }\end{array}$ & $\begin{array}{l}\text { with whether this investor is an active or passive investor. The Effective Market Hypothesis argues } \\
\text { that the price of financial assets cannot be estimated by studying past price indices and other } \\
\text { studies on assets. }\end{array}$ \\
\hline
\end{tabular}

\section{GİRIŞ}

Etkin Piyasa Hipotezi (EPH) kavramı finansal varlık fiyatlarının bu finansal varlıkla ilgili tüm bilgileri yansıttığını varsaymaktadır. EPH'ne göre aktif bir yatırımcı finansal piyasalarda nasıl sürekli karlı işlemler yapamayacaksa, pasif yatırımcılar da yaptıkları alım ve satım hamleleri ile bir aktif yatırımcının sağladığı kadar kârı elde edebilme olanağına sahiptir (Harder, 2008). Bu durumda EPH piyasanın herhangi birisi tarafından alt edilebilmesinin olanaklı olmadığını savunmaktadır. Piyasada oluşan varlık fiyatları çoğunlukla doğrudur.

Hisse senedinin piyasaya çıktıktan sonraki fiyatını arz ve talep oluşturmaktadır. Arz ve talebin etkileşmesi ile bir taraftaki satıcının satmak istediği ve diğer taraftaki alıcının almak istediği para değeri düzeyinde fiyat oluşmakta ve fiyat hisse senedinin ederi olarak belirlenmektedir. Hisse senedinin satış fiyatı o ana kadar 
içerdiği bilgiyi ve geleceğe ait varsayımları içermektedir. Finansal varlığı satın almak isteyen yatırımcı, hisse senedinin değerinin ne olacağı ve gelecekteki kâr payı getirilerini tahmin ederek bu varlığı alıp almamaya karar verir. Hisse senedinin riskini, hisse senedini piyasaya arz eden kurumun gelecekteki pazar değerini ve ne kadar kâr elde edeceğini tahmin yürütecektir. Bu bakış açısı ile piyasa etkindir. Yatırımcı hisselerin değer kazanacağını düşünüyor ise hisse senedini alacak, hisse senedinin değer kaybedeceğini düşünüyor ise satış pozisyonu alacak, eğer hisse senedi fiyatında bir değişme olmayacağını düşünüyor ise hiçbir alım veya satım işlemi yapmayacaktır (Barnes, 2016). Sadece hisse senedi için geçerli olmayan bu alım satım kararları piyasadaki diğer mal ve hizmetler içinde geçerlidir. Bu durumda değerinin altında satışı yapılan bir gayrimenkulün hemen alıcısı ile buluşacağı değerlendirilmektedir. Çünkü gayrimenkulün yeni alıcısı değerinin altında satın aldığı konutu bir süre sonra yüksek kar elde ederek satmayı düşünerek almıştır. Değerinin altında varlıklar alım kararını değerinin üzerinde seyreden fiyatlar ise satım kararını doğurmaktadır.

EPH finansal varlıklara ait anlık fiyatların o varlıklarla ilgili her türlü bilgiyi yansıttı̆̆ını varsayarken bunun tersini savunan diğer çalışmalarda mevcuttur ve anomali olarak adlandırılmaktadır.

Bu çalı̧̧mada da S\&P 500 indeksindeki hisse senetlerinin 2010-2018 yılları arasındaki günlük getiri verilerinden oluşan seri dikkate alınarak etkin piyasa hipotezi test edilmiştir.

\section{LITERATÜR TARAMASI}

\subsection{Etkin Piyasa Hipotezi Kavramı}

Etkin piyasa hipotezinin temeli "Rassal Yürüyüş" yani "Random Walk" teorisine dayanmaktadır. Her ne kadar rassal yürüyüş hipotezi adı ile anılmasada bu konudaki ilk ampirik çalışma Louis Bachelier (1901) tarafından yapılan "The Theory of Speculation" isimli çalışma olarak kabul edilmektedir. Mal/ürün piyasası üzerine yapılan araştırmada fiyatların bir patern izlemediği görülmüştür. O yıllarda çalışma çok fikir yandaşı toplamamış ve ilgi görmemiştir.

Rassal yürüyüş hipotezi Maurice Kendall (1953) tarafından Kraliyet istatistik Derneğinin toplantısında sunulan UK hisse senedi ve temel madde fiyatlarının davranışı üzerine yapılan bir çalışma ile ortaya konulmuştur. Rassal yürüyüş veya rastgele seyir hipotezine göre birbirini izleyen günlere ait fiyat değişimleri sistematik bir yol izlememektedir. Bunun anlamı hisse senetlerinde fiyat artışlarını fiyat azalışlarının izlemesi gibi sistematik bir eğilim olmamasıdır (Brealey, Myers, Allen, Mohanty, 2003).

Rassal yürüyüş hipotezine göre, bir hisse senedinin fiyatı kümülatif tesadüfi sayılar serisinin davranışlarına benzer şekilde öngörülebilecek yapıda olmadığı gibi fiyat hareketleri üzerinde yapılan çalışmalar ile gelecekteki fiyat hareketlerinin tahmin edilmesinde kullanılması olanaklı değildir (Bildik, 2000).

Rassal yürüyüş hipotezinin ortaya atılmasından uzun yıllar sonra; Paul Samuelson (1965) ve Eugene Fama (1965) bu konuya ilgi duyup yeni çalışmalar yapmışlardır. Birbirinden bağımsız olan bu iki çalışma da hisse senedi fiyatlarındaki rassal yürüyüşü araştırmaktadır. "Etkin" pazar, önemli tüm güncel bilgilere neredeyse tüm katılımcıların serbestçe ulaşabildiği, çok sayıda katılımcının olduğu rekabetçi piyasalardır. Bu katılımcılardan her biri varlıkların gelecekteki piyasa değerlerini tahmin etmeye ve rasyonel kar maksimizasyonu sağlamaya çalışmaktadır (Fama, 1965). Bu çalışmaların ardından Etkin piyasa hipotezi adı altında ilk çalışma yine Fama (1970) tarafından ortaya konmuştur.

Etkin piyasa hipotezi başlıca üç varsayımı kabul etmektedir (Barone, 2003). Birinci varsayım yatırımcıların rasyonel olduğu varsayımıdır. İkinci varsayım ise yatırımcıların tam bilgiye sahip olabileceğini söylemektedir. Son varsayım ise yatırımcıların faydalarını maksimize etmeyi beklediklerini kabul etmektedir.

Etkin Piyasa Hipotezinin geçerliliğinde pazarın işleyişi ve yatıımının davranışları ile ilgili de varsayımlar bulunmaktadır. Bu varsayımlar Thaler (1987) tarafından;

- Yatırımcının temel amacı, nihai zenginliğin faydasını artırmak olduğu,

- Yatırımcının risk ve getiri temeline dayalı seçimler yaptığı,

- Yatırımciların risk ve getiri beklentilerinin homojen olduğu, 


\section{N. Komşuoğlu Yılmaz 11/3 (2019) 1559-1574}

- Piyasada bilginin serbestçe hareket edebildiği ve tüm rasyonel bireyler tarafından bilgiye kolayca ulaşılabildiği şeklinde sıralanmıştır.

Bu teoriye göre piyasada hisse senedi fiyatı oluşurken menkul kıymetle ilgili tüm bilgiler fiyat oluşumuna zaten yansımakta olup geleceğe yönelik tahminler için yansıyan bilgilerin kullanılmayacağı anlatılır. Varlık fiyatlarının tüm bilgiyi yansıtması durumu piyasaların etkin işlemesi anlamına gelmektedir. Hisse senedi fiyatlarının piyasada tüm bilgiyi zaten ve tamamen yansıtması sonucunda bilgileri kullanarak piyasa ortalamasının üzerinde ekstra bir getiri elde ederek piyasayı alt etmek mümkün değildir.

Etkin Piyasa Hipotezi mükemmel piyasaların davranışlarını açıklayan bir teori olmakla birlikte bu piyasanın özellikleri aşağıda sıralanmıştır (Aydın, Başar ve Coşkun, 2010):

- Menkul kıymet fiyatları dengededir. Menkul kıymetler adil olarak fiyatlandırılmıştır.

- Beklenen getiriler tahmini getirilere eşittir.

- Herhangi bir zamanda, menkul kıymet fiyatları menkul kıymetler ve işletmelerle ilgili tüm bilgileri yansıtmaktadır. Piyasaya yeni bilgiler geldiğinde menkul kıymet fiyatları değişmektedir.

- Menkul kıymetler adil fiyatlandırıldığından yatırımcılar yanlış fiyatlandırılmış menkul kıymetleri bulmak için zaman harcamazlar.

Fama (1970) piyasa etkinliğini üç kategoriye ayırmıştır: Bu üç kategori (1) Zayıf Formda Piyasa Etkinliği, (2) Yarı Güçlü Formda Piyasa Etkinliği ve (3) Güçlü Formda Piyasa Etkinliği olarak sıralanmaktadır.

Zayıf formda piyasa etkinliğine göre yatırımcı geçmiş fiyat hareketlerine çalışarak gelecekteki fiyat oluşumlarını tahmin edemez. Fiyatlar tesadüfi değişim göstermekte hiçbir ardışık basamakta birbirini takip eden bir patern izlememektedir. Piyasada rastgele yürüyüş olduğu için geçmiş fiyat bilgileri geleceğe yönelik bir 1şık tutmakta yetersiz kalacaktır. Zayıf formda etkinliğin testi rassal yürüyüş modelinin testine dönüşmekle birlikte Fama (1970) çalışmasında rassal yürüyüşün test edilmesinde üç farklı analiz yöntemi kullanmıştır. Bunlar "Serisel Korelasyon", "Run Testi” ve "Filtre Kuralı Testi”dir (Kıyılar ve Akkaya, 2016). Ayrıca zaman serileri kullanılarak test edilmesi de olanaklıdır.

Yarı güçlü formda etkinlik ise zayıf formdaki etkinlik unsuru olan geçmiş fiyat bilgilerine ek olarak halka açık tüm bilgileri de yansıtmaktadır. Halka açık tüm bilgiler mali tablolar, temettü ödemeleri ve şirketlerin birleşme, devir, F/K(fiyat/kazanç) oranlarına ilişkin ve ilaveten politik ve makro ekonomik olaylara yönelik bilgilerin tamamını içermektedir (Eken ve Adalı, 2008). Yarı güçlü formdaki etkinlik testleri zayıf formun testinde kullanılan serisel korelasyon, run testi ve filtre kuralı etkinlik testlerini de içermektedir. Amaç, hisse senedi fiyatlarının kamuya açıklanan bilgiye göre ne hızla ayarlandığını ve kamuya açıklanan herhangi bir bilgiye bağlı bir alım satım sistemi ile normalin üstünde kar elde edilip edilmeyeceğini tespit etmektedir. Ayrıca olay çalışması yöntemi bu tipte etkinliğin test edilmesi için kullanılan en yaygın yöntemdir. Piyasada oluşmuş bir haberin hisse senedinde yarattığı değişimi irdelemek için kullanılmaktadır (Kıyılar ve Akkaya, 2016). "Hisse Senedi Bölünmeleri Testi", "Yılllk Kazanç Duyuruları Testi" ve "Aracı Kurum Önerileri Testi" bu tipte etkinliğin test edilmesinde kullanılmaktadır.

Güçlü formda etkinlik ise geçmiş fiyat bilgileri ve halka açık bilgilere ek olarak içerden gelen bilgiyi yani ayrıcalıklı bilgiyi yansıtıyor olduğunu savunmaktadır. Güçlü formda etkin piyasa hipotezine göre iç bilgiye sahip olanlar bile pazarı alt edemezler (Malkiel, 1994). Güçlü formda etkinliğin test edilmesine olanak sağlayan bir teknik olmamakla birlikte bunun sebebi içeriden edinilen bilgi sahiplerine ulaşmanın tam olarak olanaklı olmamasıdır. Ancak yarı güçteki etkinliği test etmede kullanılan normal üstü getirinin izlenmesi bir yöntem olarak kullanılabilmektedir (Kıyılar ve Akkaya, 2016). “İçeriden Öğrenenlerin Ticaretine Yönelik Testler" ve "Yatırım Fonları ve Büyük Portföylerin Yöneticilerine Yönelik Testler" güçlü formdaki etkinliğin test edilmesinde kullanılabilir. 


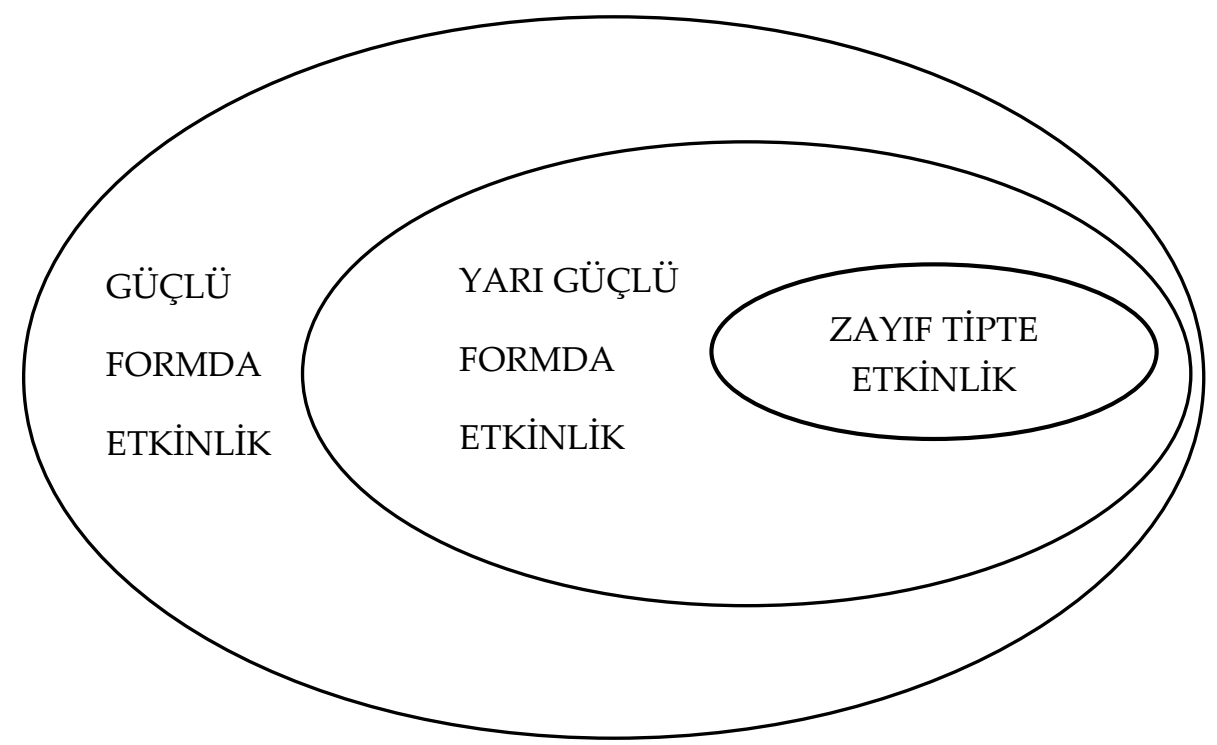

Zayıf Form Etkinlik $\subset$ Yarı Güçte Etkinlik ve Yarı Güçte Etkinlik $\subset$ Güçlü Form Etkinlik

Grafik 1: Etkin Piyasa Hipotezinde Etkinlik Tipleri

Kaynak: Kratz, Oliver S.(1999) Frontier Emerging Equity Markets Securities Price Behavior and Valuation, Kluwe Academic Publishers.America.S.20

Şekil 1'de görüldüğü üzere yarı güçte tip etkinlik aynı zamanda zayıf form etkinlik kriterlerini de içermekte, güçlü form etkinlik ise yarı güçlü ve zayıf tip etkinliği de kapsamakta olduğu görülmektedir.

\subsection{Etkin Piyasa Hipotezi Üzerine Çalışmalar}

Finansal piyasaların etkinliği konusunda literatürde çok sayıda araştırma mevcuttur. Etkinlik tipini ölçmede birçok test geliştirilmiş ve farklı sonuçlar bulunmuştur. Bazı çalışmalar etkin piyasayı kabul ederken bazı çalı̧̧malarda bu hipotezi reddeden sonuçlara rastlanmaktadır.

Deng (2007) çalışmasında etkin piyasa hipotezinin borsa gerçeklerine uygunluğunun çok uzak olduğu ve bilimsel içeriğinin sıfıra yakın olduğu sonucuna varmıştır.

Harvey (1993) gelişmekte olan ülkelerdeki 20 hisse senedi piyasasını inceleyen çalışmasında getirileri tahmin etmek için hem dünya hem de yerel bilgi değişkenleri kullanılabileceğini ve etkinliğin düşük olmasından yola çıkarak bu ülkelere yatırım yapılmasını önermiştir.

Kasman ve Kırkulak (2007) geleneksel birim kök ve yapısal kırılmalı birim kök testlerini kullanmış ve senet fiyatlarında zayıf formda etkin piyasa hipotezini araştırarak piyasanın etkin olduğunu, diğer bir ifadeyle rassal yürüyüş gösterdiğini tespit etmiştir.

Kılıç ve Buğan (2016) çalışmalarında etkin piyasa hipotezinin testi için BIST 30, BIST 50 ve BIST 100 endekslerini kullanmıştır. İlk olarak Harvey'in doğrusallık testi uygulanmıştır. Lineer bir davranış tespit edilmemiş, ardından Kapetanios vd. (2003) ve Kruse (2011) tarafından uygulanan lineer olmayan birim kök testi uygulanmış ve Kapetanios vd. (2003) sonucunda EPH kabul edilmiş ancak Kruse (2011) testi EPH'ni red etmiş̧ir.

Balaban (1995) Menkul Kıymetler Borsası'nın Ocak 1988-Ağustos 1994 dönemi için Endeks bilgi etkinliğini test etmiş zayıf form ve yarı güçlü formda etkinlik red edilmiştir.

Ma ve Barnes (2001) araştırmalarında Shanghai ve Shenzhen borsalarında etkinlik düzeyi üzerine çalışmışlardır. 1990-1998 dönemi günlük, haftalık ve aylık frekanslar ile incelenmiştir. Etkinlik seri korelasyon, Run testi ve varyans oran testleri kullanılarak test edilmiştir.

Çevik ve Erdoğan (2011) çalışmalarında 2003-2007 aralığında Türkiye'de bankacılık sektörünün durumunu araştırılmıştır. Araştırma sonuçları, araştırılan sektörün zayıf formda etkin olmadığını ortaya koymuştur. 
Zeren, Kara ve Arı (2013) çalışmalarında ulusal hisse senedi piyasasının zayıf formda etkinliğini rassal yürüyüş modeli çerçevesinde İMKB 100 indeksini esas alarak 30 yıllık veriyi Lanne vd. (2002) ile Saikkonen ve Lutkepohl (2002) tarafından geliştirilen yapısal kırılmalı birim kök testi kullanılarak analiz etmişlerdir. İMKB 100 endeksinin durağan olmadığı bulgusuna ulaşılmış ve Türk hisse senedi piyasasının etkin olduğu gösterilmiştir.

Demireli, Akkaya ve İbaş (2010)'ın S\&P 500 endeksine ait haftalık getiri serilerini test ettikleri çalışmalarının sonucu hisse senetlerinin rassal yürüyüş hipotezine uygun davrandığını diğer bir deyişle endekste yer alan hisse senetlerinin fiyatlarının önceki dönem fiyatlarından bağımsız hareket ettiği tahmininde bulunmuşlardır.

Awad ve Daraghma (2009) yaptıkları araştırmada, Filistin Borsası'nda işlem gören 35 hisse senedinde zayıf etkinliği, günlük getirilere göre parametrik ve parametrik olmayan testler ile ölçmüştür. Araştırmanın sonucunda borsanın zayıf formda dahi etkin olmadığı tespit edilmiştir.

Kian-Ping vd. (2003), Malezya' daki Kuala Lumpur borsasında etkinlik varlığını saptamak amacı ile 1990-2002 döneminde günlük kapanış değerleri verilerine Hinich ve Patterson (1995)'un Windowed Test prosedürünü uygulamışlardır. Sonuç olarak araştırılan borsanın zayıf formda etkin davrandığı belirlenmiştir.

\subsection{Anomaliler}

Etkin piyasanın varlığı ile ilgili tüm teoriler Fama gibi düşünmemekte, Fama'nın piyasa hipotezini eleştirmektedir. Örneğin, etkin piyasa hipotezi fiyatların öngörüsünde kullanılan teknik ve temel analiz yaklaşımlarını geçersiz sayar. Davranışsal finans alanında ise piyasalarda bazı anomaliler olduğunu tespit eden akademik çalışmalar etkin piyasalar hipotezi eleştirilmektedir. Etkin piyasalar hipotezinin savunduğu geçmişe ait veriler, halka açı bilgiler ve iç bilgiler bilinmesi piyasaların geleceğini tahmin etmekte ve piyasalarda alım satım yaparak üstün kar elde etmekte kullanılamayacağı şeklindeki varsayımın aksine davranışsal finans yaklaşımları, psikolojik nedenlerle yatırımcıların her zaman rasyonel olamayacaklarını savunur. Bu nedenle piyasalarda fiyatlanmanın belli bir patern izleyebileceği düşüncesi savunulur. Haftanın günleri etkisi, Ocak ayı anomalisi, ay içi anomalisi, tatil öncesi anomalisi, düşük fiyatlı hisse senedi anomalisi ve firma büyüklüğü anomalisi bilinen anomalilerden bazılarıdır. Tablo 1'de anomaliye ait bazı tanımlar sunulmuştur.

Tablo 1: Finansal Piyasa Anomali Tanımları

\begin{tabular}{|l|l|}
\hline SANTOS, Ana C., 2011 & $\begin{array}{l}\text { Fayda maksimizasyonu ile çelişen karar ve seçim } \\
\text { kalıpları. }\end{array}$ \\
\hline BRAV, Alon; HEATON, John B., 2002 & $\begin{array}{l}\text { Finansal bir anomali, geleneksel etkin piyasa hipotezi } \\
\text { ve arbitraj fiyatlama modeli ile bağdaşmayan belli bir } \\
\text { fiyat davranısının belgelenmiş bir modelidir. }\end{array}$ \\
\hline DENG, Min., 2007 & $\begin{array}{l}\text { Anomali, beklenmedik olaya işaret eder ve } \\
\text { yatırımcıların mevsimsel anormallikler gibi anormal } \\
\text { getiri elde etmeleri için fırsatlar yaratabilir. }\end{array}$ \\
\hline SZYSZKA, Adam., 2007 & $\begin{array}{l}\text { Geleneksel finansal ekonomi çerinde } \\
\text { açıklanması zor olan gözlemlere anomali denir. }\end{array}$ \\
\hline KANTOLINSKIY M.I., 2010 & $\begin{array}{l}\text { Piyasadaki etkin pazar hipotez modeline kıyasla daha } \\
\text { yüksek gelir elde edebilen kararlı yapılandırmalar. }\end{array}$ \\
\hline BLOOMFIELD, Robert, 2010 & Paradigma ile çelişen gözlemlerdir. \\
\hline
\end{tabular}

Kaynak: Kartašova, Jekaterina \&Vicoskaitė, Ina, (2013)

Etkin piyasa hipotezini dışlayan ve bazı normları izleyerek piyasada yüksek getiri kazanılacağını savunan akademik çalışmalar ve teoriler vardır. Günlere, aylara, bazı tatil günlerine ilişkin anomaliler döneme ait anomalilerdir. Dönemsel olmayan anomalilerden bazıları firma büyüklüğü etkisi, Piyasa değeri / Defter değeri oranı, Fiyat / Kazanç oranı etkisi, Fiyat /Satış oranı etkisi, Fiyat / Nakit akım oranı etkisi, Temettü verimi etkisi ve Önceki getiri etkisidir. Teknik anomaliler ise hareketli ortalamalar ve Destek - Direnç hesaplamalarıdır (Turaboğlu ve Topaloğlu, 2017). Bu anomaliler bazı araştırmalarda belirgin bir şekilde görülse de tam güvenilir olduğu söylenemez. Anomaliler bir kez meydana gelebilir ve sonra yok olabilir veya tekrar tekrar 


\section{N. Komşuoğlu Yılmaz 11/3 (2019) 1559-1574}

meydana gelebilir. Araştırmalarda kullanılan farklı dönemlere ait veriler farklı bulgular ile sonuçlanabilir. Bu üstün kazançların her piyasada mutlaka var olacağı ve süreklilik arz edeceği anlamına gelmez ve güvenilirlik arz etmez.

\subsubsection{Dönemsel Anomaliler}

Döneme ait anomaliler yani dönemsel anomaliler belli bir dönem öncesi ve sonrası oluşan anomalilerdir. Mevsimsel anomaliler haftanın bazı günlerine ait veya özel tatil günlere ait olan ve bu zaman aralıklarında yapılan alım satım işlemlerinden olağan üstü kar elde etmenin mümkün olduğunu varsayar.

Hafta sonu etkisi, Pazartesi günü fiyatlardaki düşme ile ilgili bir anomalidir. Cuma ve Pazartesi günkü kapanış fiyatları karşılaştırldığında Pazartesi günkü kapanış fiyatının daha düşük olduğu iddia eder (Smirlock ve Starks, 1986).

Ocak ayı etkisi döneme ait en çok test edilen anomalilerden biridir. Bu anomali Ocak ayında menkul kıymet piyasasında alımların arttığı ve talebin artmasının doğal bir etkisi oluşarak hisse senedi fiyatlarında da bir artış olduğunu açıklamaktadır. Haugen ve Lakonishok (1988) The Incredible January Effect isimli kitap çalışmalarında Ocak ayı etkisinin yanı sıra haftanın bazı günleri etkisin varlığınıda göstermiştir (Haugen ve Lakonishok, 1988). Ocak ayında hisse senetlerinin fiyatlarının artmasının nedeni araştıracılar tarafından "Vergi Kaybı Hipotezi" olarak gösterilir. Aralık ayında elindeki hisseleri satan yatırımcılar hisse senedinde fiyatların düşmesine neden olur. Bir sonraki ay yani Ocak ayında ise tekrar alış pozisyonuna geçerek hisse fiyatlarında artmaya neden olur. Aralık ayında ise genel olarak fiyatlarda düşüş sebebiyle oluşan kayıplarını vergiden düşme yoluna gitmektedirler (Çinko, 2008).

Haftanın bazı günleri etkisini araştıran dünyanın çeşitli ülkelerinin endekslerinin kullanıldığı ve etkin piyasa anomalisi üzerine yapılan çalışmalar da mevcuttur. Dünyanın çeşitli ülkelerindeki endekslerin kullanılarak yapıldığı etkin piyasa anomalisini tespit etmek isteyen çalışmalar mevcuttur. Jaffe ve Westerfield (1985) dört farklı ülke endekslerini kullanarak yaptığı çalışmasında Avustralya ve Japonya'da Salı günleri getiri azalışını tespit etmişlerdir. Amerika, İngiltere ve Japonya için haftanın günü etkisini tespit edilmiştir (Jaffe ve Westerfield, 1985). Agrawal \& Tandon (1994) Avrupa, Asya, Avustralya ve kuzey ve güney Amerika'da 18 ülke endekslerini dahil ettikleri çalışmalarında 9 ülke için Pazartesi günleri düşük getiri ve 8 ülke için Salı günü etkisini ve Lüksemburg hariç tüm ülkelerde Cuma günleri pozitif bir getiri etkisini ortaya koymuşlardır (Agrawal ve Tandon, 1994). Keim NYSE ve AMEX hisse senedi piyasası verilerini kullanan çalışmasında Ocak ayındaki günlük anormal getiri dağılımlarının, geriye kalan on bir aya göre büyük araçlara sahip olduğu ve Ocak ayında anormal getirisinin de firma büyüklüğü arasındaki ilişkinin her zaman olumsuz olduğu ve herhangi bir aydan daha belirgin olduğu kanıtlanmıştır (Keim, 1983).

\subsubsection{Dönemsel Olmayan Anomaliler}

Belli bir zaman veya zaman dilimi ile ilgili olmayan anomaliler firma büyüklügü etkisi, Piyasa değeri / Defter değeri oranı, Fiyat/Kazanç Oranı etkisi, Fiyat / Nakit akım oranı etkisi, Temettü verimi etkisi ve Önceki getiri etkisidir.

Firma büyüklügü etkisinin tespiti için Banz (1981) araştırmasında NYSE ortak stoklarının getirisi ile toplam piyasa değeri ilişkisine bakılmıştır. Araştırmada daha küçük boyutlu işletmelerin ortalama olarak büyük ölçekli işletmelerin üzerinde risk ayarlı getirileri olduğu bulunmuştur. Ayrıca boyut etkisinin piyasa değerin ile doğrusal olmadığını asıl etkinin çok küçük firmalar için gerçekleşirken, ortalama büyüklük ve büyük firmalar arasında çok az fark olduğunu tespit etmiştir.

Piyasa değeri / Defter değeri oranı şirketin değerlemesinde kullanılan bir orandır. Bir hissenin piyasa fiyatı ile hisse başına düşen öz sermayenin oranıdır. Değerin düşük olması işletmenin piyasa değerinden düşük olduğu sonucunu vermektedir.

Aksu ve Önder (2000) firma büyüklüğü ve piyasa-defter değerleri ile hisse senedine ait getiriler arasındaki ilişkiyi araştırmıştır. Hem boyut hem de piyasa- defter değerinin getiri ile ilişkili olduğunu belirlemiştir.

Taner ve Kayalıdere (2002) üretim sektöründe işletme büyüklüğü değişkenini kullanarak 1995-2000 yılları arasını kapsayacak şekilde verileri kullanmış ve bu portföylerin aşırı getiri elde edilemeyeceğini tespit etmiştir. Sonuç olarak Borsa İstanbul'da firma büyüklüğü anomalisinden söz edilemeyeceği sonucuna ulaşmıştır.

Goodman ve Peavy (1983) Fiyat / Kazanç oranı düşük işletmelerin hisselerinin getirisinin daha yüksek olduğunu tespit etmiştir. 
Basu (1977) NYSE endüstri işletmelerine ait 14 yıllık veri ile yaptığı çalışmasında hisse senedi yatırım performansı ve fiyat kazanç oranı ilişkisini incelemiştir. Araştırma sonucunda düşük Fiyat-Kazanç rasyosuna sahip olan işletmelerin hisselerinden meydana gelen portföylerin, yüksek Fiyat- Kazanç rasyosuna sahip meydana gelenin üzerine getiri sağladığı ortaya konmuştur.

\subsubsection{Teknik Anomaliler}

Teknik anomaliler hareketli ortalamalar ve destek \& dirençler olarak sınıflandırılabilir. Teknik analiz piyasada oluşmuş verileri inceleyerek belli bir patern bulmaya çalışır. Teknik analiz ile piyasanın belli trendler izlendiği varsayılarak gelecekte oluşacak fiyat iniş ve çıkışları tahmin edilir. Tahminler yapılarak destek ve direnç noktaları belirlenirken alım satım kararları şekillenir. Teknik analizde fiyat oluşumları veya geleceğe dair öngörülerde istatistiksel rakam ve analizler yapılır ancak bu iniş ve çıkışların sebepleri üzerinde durulmaz. Teknik analiz daha çok kısa süreli karar verme tekniği olarak anılırken yardımcı bir analiz yöntemi olan temel analizi de buna destek verebilir.

\subsection{Araştırmanın Amacı ve Önemi}

$\mathrm{Bu}$ çalışmanın amacı Etkin Piyasa Hipotezini test ederek Standart\&Poors 500 endeksinde geçerliliğini araştırmaktır. Bu amaçla çalışmada S\&P 500 indeksindeki hisse senetlerinin 31-12-2009 ile 31-12-2018 tarihleri arasındaki günlük getiri verilerinden oluşan seri dikkate alınarak etkin piyasa hipotezi test edilmiştir. Etkin Piyasa Hipotezi bir yatırımcının finansal varlıklarından kazandığı getirinin bu yatırımcının aktif veya pasif bir yatırım yöneticisi olup olmadığı ile ilgisi olmadığını ve finansal varlıkların fiyatının geçmiş fiyat endekslerine ve varlıklara ait olan diğer bilgiler üzerine yapılan çalışmalar aracılığı ile tahmin edilemeyeceğini savunmaktadır. Araştırmanın önemi belirlenen tarih aralığında ARCH ve GARCH yöntemlerinin kullanımıyla S\&P 500 indeksinde etkin piyasa hipotezini test ederek hipotezin varsayımlarının geçerliliğini incelemeyi amaçlamış olmasıdır.

\section{ARAŞTIRMA YÖNTEMİ ve BULGULAR}

\subsection{Araştırmanın Kapsamı ve Yöntemi}

$\mathrm{Bu}$ çalışmada rassal yürüyüş hipotezi test edilmiş ve EPH'nin varlığı araştırılmıştır. Amerika'da faaliyet gösteren değeri en yüksek 500 şirketin hisse senetlerine ait verileri içeren S\&P 500 endeks verileri www.yahoofinance.com web sitesinden derlenmiştir. S\&P 500 endeksinde 31-12-2009 ile 31-12-2018 tarihleri arasındaki günlük kapanışlar dikkate alınarak kapanış fiyatlarının bir patern izleyip izlemediği yani rassal yürüyüş hipotezinin varlığı test edilmiştir. Günlük logaritmik getiri serisi aşağıdaki formül kullanılarak hesaplanmıştır.

$$
R_{(D, T)}=\ln \left(\frac{P_{(D, T)}}{P_{(D, T-1)}}\right)
$$

Grafik 2: S\&P 500 2010-2018 Kapanış Fiyat Grafiği ve Getiri Grafiği

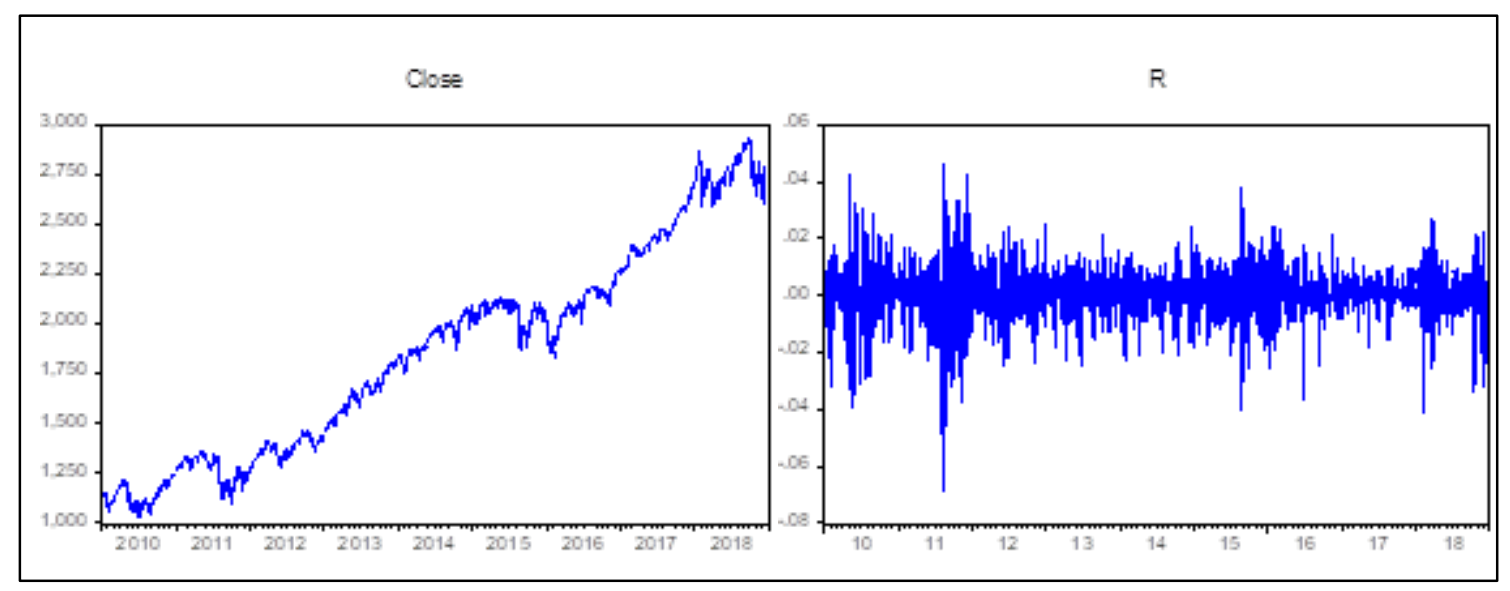

Zaman serilerinde önce birim kök olup olmadığ tespit edilmelidir. Stokastik zaman serilerinde serinin durağan olup olmaması önem taşır. Seri durağan değil ise araştırma sonucu sadece alınan dönem için geçerli olacak ve bir genelleme yapılamayacaktır. Durağan olmamanın belirleyicileri zaman serisinin ortalamasının tanımlanamaz olması, varyansının sonsuz olması, herhangi bir şokun ortadan kalkmaması ya da zaman 
serilerinin izlediği seyrin değişmesidir (Özarı, 2013). Serinin durağan olması rassal yürüyüşün olmadığı yani EMH'nin geçerli olmadığını, serinin durağan olmaması EMH'nin geçerli olduğunu gösterecek kanıtlardır.

Literatürde durağanlık tespiti için en çok kullanılan birim kök ve durağanlık inceleyen testler Dickey-Fuller testleri (DF/ADF), Philips-Perron birim kök testi (PP) ve Kwiatkowski-Phillips-Schmidt-Shin birim kök testi (KPSS)'dir.

Bu çalışmada Dickey-Fuller Birim Kök Testi, Phillips Perron testi ve ARMA testi ve ARCH ve GARCH modeli kullanılmıştır. 2265 güne ait kapanış fiyatlarının dahil edildiği çalışmada veri setine ait tamamlayıcı istatistikler Tablo 2' de sunulmuştur.

Tablo 2: Tamamlayıcı İstatistikler

\begin{tabular}{|c|c|c|c|c|c|}
\hline & $\begin{array}{c}\text { Kapanış } \\
\text { Fiyatları }\end{array}$ & $\mathbf{R}$ & & $\begin{array}{c}\text { Kapanış } \\
\text { Fiyatları }\end{array}$ & $\mathbf{R}$ \\
\hline Ortalama & 1856.456 & 0.000358 & Basıklık & 1.955039 & 7.585938 \\
\hline Medyan & 1904.010 & 0.000535 & Jarque-Bera & 120.7813 & 2070.667 \\
\hline Maksimum & 2930.750 & 0.048403 & Olasılık & 0.000000 & 0.000000 \\
\hline Minimum & 1022.580 & -0.068958 & Toplam & 4204873. & 0.810083 \\
\hline Standart Sapma & 520.7487 & 0.009468 & Standart Sapma Toplamı & $6.14 \mathrm{E}+08$ & 0.202857 \\
\hline Çarpıklık & 0.216713 & -0.479509 & Gözlem Sayıs & 2265 & 2264 \\
\hline
\end{tabular}

\subsection{Dickey-Fuller Birim Kök Testi}

Dickey ve Fuller (1979) tarafından geliştirilen Dickey-Fuller Birim Kök Testi ilk kez "Distribution of the Estimators for Autoregressive Time-Series with a Unit Root" adlı makale ile duyurulmuştur. Bu test ile zaman serilerinde birim kök varlığı- serinin durağan olup olmadığı- araştırılmaktadır. Hata terimi varsayımsal olarak ortalaması sıfır, eş-varyanslı (homoskedastic) ve ardışık bağımlı olmayan beyaz gürültü (white noise) terimidir ve beyaz gürültü olan bir hata terimi doğası gereği stokastik veya rassal yürüyüş modeline örnek teşkil etmektedir (myistatistik.com, 2019)

Dickey-Fuller birim kök testi aşağıdaki şekilde modellenmiştir (realtstatistics.com, 2019; Hanedar, 2019)

$$
y_{i}=\phi y_{i-1}+\varepsilon_{i}
$$

عi' stokastik hata terimi olmak üzere, yukarıdaki eşitliğin bir birim kökü olup olmadığını belirlemek için yi-1 farkı her iki taraftan çıkarılır.

$$
\begin{aligned}
& y_{i}-y_{i-1}=\phi y_{i-1}+\varepsilon_{i}-y_{i-1} \\
& y_{i}-y_{i-1}=(\phi-1) y_{i-1}+\varepsilon_{i}
\end{aligned}
$$

Delta fark sembolü olarak kullanıldığında $\Delta y \mathrm{i}=\mathrm{yi}-\mathrm{yi}-1$ ve $\beta=\varphi-1$, eşitliği lineer regresyon eşitliği ve H0 ve H1 hipotezleri sırasıyla aşağıda sunulmuştur.

$$
\Delta y_{i}=\beta y_{i-1}+\varepsilon_{i}
$$

H0: $\beta=0$ (veya $\varphi=1), \mathrm{H} 1: \beta<0$ (veya to $\varphi<1$ )

$(\varphi-1)=0$ veya $\beta=0$ durumunda yi serisi birim kök içermektedir. Ancak $\mathrm{I} \varphi \mathrm{I}<1$ durumunda seri durağan olur. Burada Dickey ve Fuller'ın Monte Carlo uygulamasında ortaya çıkarılan " $\mathrm{T}^{\prime}$ (tau) istatistiği kullanılmaktadır (Hanedar, 2019). Hesaplanan tau değeri kritik değerler (Dickey-Fuller tablosu) tablosundaki kritik değerden düşükse, anlamlı bir sonuç elde edilir; Aksi halde, bir birim kökün varllğg ve zaman serilerinin durağan olmadığı hipotezini kabul edilir (realstatistics.com, 2019).

Dickey-Fuller'in ortaya koyduğu üç denklem türü bulunmaktadır;

Sabitsiz trendsiz Dickey-Fuller denklemi : $\Delta y i=\beta 1$ yi-1 $+\varepsilon i$

Sabitli trendsiz Dickey-Fuller denklemi : $\Delta y i=\beta 0+\beta 1 \mathrm{y} i-1+\varepsilon i$

Sabitli trendli Dickey-Fuller denklemi: $\Delta y i=\beta 0+\beta 1$ yi- $1+\beta 2 i+\varepsilon i$ 


\subsection{Phillips Perron Testi}

Dickey-Fuller Testi hata terimlerinin istatistiki olarak bağımsız olduklarını ve sabit varyansa sahip olduklarını varsayarken Genişletilmiş Dickey Fuller testi, modele gecikmeli değerler ekleyerek Dickey- Fuller testini otokorelasyon problemine karşı düzeltmiş ve sonrasında Phillips ve Perron (1988) Dickey-Fuller' in hata terimleri ile ilgili varsayımını genişletmişlerdir (Peter, 1988). PP testi ile ADF testlerinin önemli bir farklılı̆̆ PP'nin hata terimlerindeki içsel bağlantının (serial correlation) ve heteroskedastisite sorununu çözmüş olmasıdır (Zivot ve Wang, 2006). Aşağıda görülen regresyon denklemleri ile;

$\mathrm{Yt}=\mathrm{a}_{0}{ }^{*}+\mathrm{a}_{1}{ }^{*} \mathrm{yt}-1+\mu \mathrm{t}$

$\mathrm{Yt}=\mathrm{a}_{0} \bullet+\mathrm{a}_{1} \bullet \mathrm{yt}_{-1}+\mathrm{a}_{1} \bullet(\mathrm{t}-\mathrm{T} / 2)+\mu \mathrm{t}$

"T gözlem sayısını $\mu \mathrm{t}$ hata terimlerinin dağılımını göstermekte olup bu hata teriminin beklenen ortalaması sıfıra eşittir. Yukarıda bahsedildiği üzere hata terimleri arasında içsel bağlantının (serial correlation) olmadığı veya homojenlik varsayımı gerekli değildir. Bu açıdan bakıldığında Dickey-Fuller testinin bağımsızlık ve homojenite varsayımları Phillips-Perron testinde terk edilmiş hata terimlerinin zayıf bağımlılı̆̆ı ve heterojen dağ 1 lımı kabul edilmiştir" (Enders, 2014).

PP Testinde kurumuş hipotezler aşağıda sunulmuştur.

Ho: Seri birim kök içermektedir (Rassal yürüyüş modeline uygundur.)

H1: Seri birim kök içermemektedir (Durağan bir seridir.)

\subsection{Korelogram Çizimi}

Bir zaman serisinin rassal olup olmadığı yani otokorelasyon olup olmadığını test etmek için kullanılır. Eğer zaman serisi rastgele bir seyir izliyor ise AC (otokorelasyon) sıfıra yakın değerler alır. Bazen zaman serileri bir gün veya belli bir dönem gecikmeli korelasyon barıdırıyor olabilir. Korelasyonun ne kadar geriye uzandığını görebilmek için otokorelasyon fonksiyonu (ACF) değerleri elde edilir. Gecikmesi $k$ olan ACF şeklinde tanımlanır (Gujerati, 2006).

$$
\begin{aligned}
& \bar{\rho}_{k}=\frac{\overline{\gamma_{k}}}{\overline{\gamma_{0}}} \\
& \overline{\rho_{k}}=\text { k gecikmesindeki kovaryans / varyans } \\
& \overline{\rho_{k}} \text { 'nın k gecikme uzunluğuna göre çizimine korelogram adı verilmektedir. }
\end{aligned}
$$

\subsection{Otoregresif Hareketli Ortalama Modeli ARMA}

Bazı zaman serileri sadece AR veya sadece MA ile ifade edilebilirken bazı zaman serileri Otoregresif ve ve hareketli ortalama modellerinin bileşimi olan ARMA ile ifade edilir. AR ve MA bileşenleri $p$ ve q'uncu dereceden olmak üzere ARMA $(\mathrm{p}, \mathrm{q})$ olarak tanımlanabilir. $\mathrm{p}$ ve $\mathrm{q}$ 'nun kaç gecikmeli olarak hesaplanacağı korelogram testinden elde edilecek sonuca göre belirlenebilir.

Bu modelin, bir zaman serisinin herhangi bir $t$ dönemine ait xt gözlem değeri, ondan önceki belirli sayıda xt$1, \mathrm{xt}-2, \ldots \mathrm{xt}-\mathrm{p}$ gözlem değerlerinin ve at , at- 1, at $-2, \ldots$ at-q hata terimlerinin doğrusal birleşiminden meydana gelen bir ARMA (p, q) modelinin genel ifadesi aşağıdaki şekilde yazılabilir (Bircan ve Karagöz, 2003; Carnot, Koen ve Tissot, 2005).

$\mathrm{xt}_{\mathrm{t}}=\varphi_{1} \mathrm{x}_{\mathrm{t}-1}+\varphi_{2} \mathrm{x}_{\mathrm{t}-2}+\ldots+\varphi_{\mathrm{p}} \mathrm{x}_{\mathrm{t}-\mathrm{p}}+\mathrm{at}_{\mathrm{t}}-\theta_{1} \mathrm{at}_{\mathrm{t}-1}-\theta_{2} \mathrm{att}_{\mathrm{t}-2-\ldots}-\theta_{\mathrm{q}} \mathrm{at}-\mathrm{q}$

$\mathrm{xt}_{\mathrm{t}}-\left(\varphi_{1} \mathrm{x}_{\mathrm{t}-1}+\varphi_{2} \mathrm{x}_{\mathrm{t}-2}+\ldots+\varphi_{\mathrm{p}} \mathrm{x}_{\mathrm{t}-\mathrm{p}}\right)=\mathrm{at}_{\mathrm{t}}-\theta_{1} \mathrm{at}_{\mathrm{t}-1}-\theta_{2} \mathrm{at}_{\mathrm{t}-2-\ldots}-\theta_{\mathrm{q}} \mathrm{at}-\mathrm{q}$

\subsection{Veri Seti ve Bulgular}

Bu çalışmada S\&P 500 endeksinde yer alan 31-12-2009 ile 31-12-2018 tarihleri arasındaki günlük kapanışlar dikkate alınarak hesaplanmış getirilerin bir patern izleyip izlemediği yani rassal yürüyüş hipotezinin varlığı 
N. Komşuoğlu Yılmaz 11/3 (2019) 1559-1574

sırası ile ADF birim kök testi, PP Testi, korelogram, ARMA, ARCH ve GARCH testleri kullanılarak araştırılmıştır.

Tablo 3: Dickey-Fuller Birim Kök Testi Raporu

\begin{tabular}{|c|c|c|c|}
\hline \multicolumn{4}{|c|}{ Null Hypothesis: $R$ has a unit root } \\
\hline \multicolumn{4}{|l|}{ Exogenous: None } \\
\hline \multicolumn{4}{|c|}{ Lag Length: 0 (Automatic - based on SIC, maxlag=26) } \\
\hline & & t-Statistic & Prob.* \\
\hline \multicolumn{2}{|c|}{ Augmented Dickey-Fuller test statistic } & -49.60344 & 0.0001 \\
\hline \multirow[t]{3}{*}{ Test critical values: } & $1 \%$ level & -2.565984 & \\
\hline & $5 \%$ level & -1.940964 & \\
\hline & $10 \%$ level & -1.616605 & \\
\hline
\end{tabular}

Augmented Dickey-Fuller test istatistiksel sonucuna göre $t$ istatistik değeri ( $\propto \propto$ ) $-49,60$ bulunmuştur. Hipotezler aşağıdaki şekilde kurulmuştur:

Ho: Seri birim kök içermektedir (Rassal yürüyüş modeline uygundur).

H1: Seri birim kök içermemektedir (Durağan bir seridir ve rassal yürüyüş modeline uygun değildir) şeklindedir.

Kritik test sonuçlarının \%1, \%5 ve \%10 anlamlılık seviyesinde kritik test sonuçları ile karşılaştırıldığında t $\propto$ değeri kritik değerlere göre daha küçük olduğundan Ho hipotezi reddedilerek serinin durağan olduğu saptanmıştır. Daha açık bir ifade ile $\mathrm{H}_{1}$ hipotezi kabul edilmiştir.

Tablo 4: Phillips Perron Testi

\begin{tabular}{|c|c|c|c|}
\hline \multicolumn{4}{|c|}{ Null Hypothesis: $\mathrm{R}$ has a unit root } \\
\hline \multicolumn{4}{|l|}{ Exogenous: None } \\
\hline \multicolumn{4}{|c|}{ Bandwidth: 23 (Newey-West automatic) using Bartlett kernel } \\
\hline & & Adj. t-Stat & Prob. $^{*}$ \\
\hline Phillips-Per & tatistic & -50.25481 & 0.0001 \\
\hline Test critical values: & $1 \%$ level & -2.565984 & \\
\hline & $5 \%$ level & -1.940964 & \\
\hline & $10 \%$ level & -1.616605 & \\
\hline
\end{tabular}

Aynı zaman serisinin bir patern izleyip izlemediği yani rassal yürüyüş hipotezinin varlığı Phillips Perron Testi birim kök testi ile sınanmıştır. PP Test raporu Tablo 4'te sunulmuştur.

Phillips Perron Testi sonuçlarına bakıldığında bulunan değerler istatistiksel olarak anlamlı çıkmış olup ( $\mathrm{p}=0.0001$ ) serinin durağan olduğu sonucuna varılmıştır. Daha açık bir ifade ile rassal yürüyüş modeline uygun değildir.

ARMA modeli kurulmadan önce durağanlık bağımsız çizime dayanan korelogram yardımı ile bakılarak sonuçlar Tablo-5'de sunulmuştur: 
N. Komşuoğlu Yılmaz 11/3 (2019) 1559-1574

Tablo 5: Bağımsız Çizime Dayanan Durağanlık Testi

\begin{tabular}{|c|c|c|c|c|c|c|}
\hline Autocorrelation & Partial Correlation & & $\mathrm{AC}$ & PAC & Q-Stat & Prob \\
\hline |' & di' & $\begin{array}{r}1 \\
2 \\
3 \\
4 \\
5 \\
6 \\
7 \\
8 \\
9 \\
10 \\
11 \\
12 \\
13 \\
14 \\
15 \\
16 \\
17 \\
18 \\
19 \\
20 \\
21 \\
22 \\
23 \\
24 \\
25 \\
26 \\
27 \\
28 \\
29 \\
30 \\
31 \\
32 \\
33 \\
34 \\
35 \\
36 \\
\end{array}$ & $\begin{array}{r}-0.043 \\
0.014 \\
-0.042 \\
-0.009 \\
-0.075 \\
-0.004 \\
0.006 \\
-0.028 \\
-0.023 \\
0.036 \\
0.016 \\
-0.000 \\
-0.000 \\
-0.053 \\
-0.036 \\
0.022 \\
0.040 \\
-0.020 \\
-0.035 \\
0.030 \\
0.009 \\
-0.036 \\
0.030 \\
0.017 \\
-0.072 \\
-0.025 \\
0.019 \\
0.004 \\
0.016 \\
0.016 \\
-0.043 \\
-0.029 \\
0.003 \\
-0.001 \\
-0.016 \\
0.018 \\
\end{array}$ & $\begin{array}{r}-0.043 \\
0.013 \\
-0.041 \\
-0.013 \\
-0.075 \\
-0.012 \\
0.006 \\
-0.034 \\
-0.028 \\
0.029 \\
0.016 \\
-0.002 \\
-0.003 \\
-0.056 \\
-0.036 \\
0.022 \\
0.037 \\
-0.021 \\
-0.043 \\
0.025 \\
0.014 \\
-0.037 \\
0.020 \\
0.019 \\
-0.064 \\
-0.029 \\
0.009 \\
0.000 \\
0.017 \\
0.008 \\
-0.044 \\
-0.027 \\
-0.006 \\
-0.008 \\
-0.010 \\
0.012 \\
\end{array}$ & $\begin{array}{l}4.1949 \\
4.6648 \\
8.6663 \\
8.8510 \\
21.620 \\
21.651 \\
21.739 \\
23.470 \\
24.653 \\
27.546 \\
28.130 \\
28.130 \\
28.130 \\
34.510 \\
37.481 \\
38.545 \\
42.280 \\
43.153 \\
45.974 \\
48.007 \\
48.182 \\
51.077 \\
53.096 \\
53.756 \\
65.496 \\
66.970 \\
67.772 \\
67.810 \\
68.432 \\
69.048 \\
73.247 \\
75.166 \\
75.191 \\
75.195 \\
75.798 \\
76.529 \\
\end{array}$ & $\begin{array}{l}0.041 \\
0.097 \\
0.034 \\
0.065 \\
0.001 \\
0.001 \\
0.003 \\
0.003 \\
0.003 \\
0.002 \\
0.003 \\
0.005 \\
0.009 \\
0.002 \\
0.001 \\
0.001 \\
0.001 \\
0.001 \\
0.000 \\
0.000 \\
0.001 \\
0.000 \\
0.000 \\
0.000 \\
0.000 \\
0.000 \\
0.000 \\
0.000 \\
0.000 \\
0.000 \\
0.000 \\
0.000 \\
0.000 \\
0.000 \\
0.000 \\
0.000\end{array}$ \\
\hline
\end{tabular}

Tablo 5'den de anlaşıldığı üzere beşinci satırda otokorelasyon ve kısmi korelasyon dikkate alınmış ve ARMA $(5,5)$ uygulanmış olup elde edilen sonuçlar Tablo 6'da sunulmuştur.

Veriler ARMA modeli ile test edilmiş ve AR değerlerin geçmişe bağımlı olduğu ve MA'nın gecikmeli hata terimlerinin şimdiki değerini etkilediği görülmektedir. ARMA modelinde ise AR(5) ve MA(5) katsayıları anlamlı çıkmış olup sonuçlar EPH ‘nin bu zaman serisi için geçerli olmadığı sonucu bulunmuştur.

Tablo 6: ARMA Testi Sonuçları

\begin{tabular}{|c|c|c|c|c|}
\hline Dependent Variable: & & & & \\
\hline Method: ARMA Max & ood (OPG & BHHH) & & \\
\hline Date: 01/03/19 Time & & & & \\
\hline Sample: $1 / 04 / 201012$ & & & & \\
\hline Included observation & & & & \\
\hline Convergence achieve & ations & & & \\
\hline & variance $\mathrm{cc}$ & nputed usir & outer pro & \\
\hline Variable & $\begin{array}{c}\text { Coeffici } \\
\text { ent }\end{array}$ & Std. Error & t-Statistic & Prob. \\
\hline $\mathrm{C}$ & 0.000356 & 0.000196 & 1.816020 & 0.0695 \\
\hline $\mathrm{AR}(5)$ & $\begin{array}{c}- \\
0.845865 \\
\end{array}$ & 0.052522 & -16.10497 & 0.0000 \\
\hline MA(5) & 0.790705 & 0.058852 & 13.43556 & 0.0000 \\
\hline
\end{tabular}

ARCH modeli kurulmadan önce kurulan ARMA $(5,5)$ modelinde ARCH etkisi olup olmadığı sinamalıdır. ARCH testinde boş hipotez p. dereceden ARCH etkisinin olmadığını iddia eder (Uğurlu,2004). Çalışmada kurulan model için $\mathrm{p}=1,2,3,4,8,12$ ve 24 için ARCH etkisi sinanmıştır. Tablo-7'de sonuçlar görülmektedir. Tüm testlerde $\mathrm{H}_{0}$ hipotezi reddedilmiş ve ARMA $(5,5)$ modelinde $\mathrm{ARCH}$ etkisi olduğu saptanmıştır. 
N. Komşuoğlu Yılmaz 11/3 (2019) 1559-1574

Tablo 7: ARCH Testi Sonuçları

\begin{tabular}{|lcccc|}
\hline ARCH LM Stat & $\mathbf{R}$ & F statistic & Prob F & Prob K $^{\mathbf{2}}$ \\
\hline ARCH(1)LM Stat & 130.6562 & 138.5394 & 0 & 0 \\
\hline ARCH(2)LM Stat & 369.1169 & 220.2553 & 0 & 0 \\
\hline ARCH(3)LM Stat & 392.3865 & 157.9810 & 0 & 0 \\
\hline ARCH(4)LM Stat & 394.6174 & 119.2600 & 0 & 0 \\
\hline ARCH(8)LM Stat & 426.4324 & 65.46585 & 0 & 0 \\
\hline ARCH(12)LM Stat & 431.2281 & 44.19003 & $\mathbf{0}$ & $\mathbf{0}$ \\
\hline ARCH(24)LM Stat & 453.9427 & 23.45677 & $\mathbf{0}$ & $\mathbf{0}$ \\
\hline Note: ${ }^{* * *}$ denotes rejection of null hypothesis at the $1 \%$ level & & \\
\hline
\end{tabular}

$\mathrm{Ho}=\mathrm{ARCH}$ etkisi yoktur.

$\mathrm{H}_{1}=\mathrm{ARCH}$ etkisi vardır.

Modelin artıkları kullanılarak GARCH $(1,1)$ modeli kurulacaktır. GARCH; modelin varyansını kendi artıklarının karesi ve gecikmeli artıklarının karesine bağlı olduğunu öne sürer (Cihangir Kurt ve Ugurlu,2007). Bollerslev (1986) tarafından geliştirilen $\mathrm{GARCH}(\mathrm{p}, \mathrm{q})$ modeli genel olarak aşağıda görülmektedir.

$\sigma_{\mathrm{t}}^{2}=\omega+\sum_{\mathrm{i}=1}^{p} \alpha_{\mathrm{i}} \mathrm{u}_{\mathrm{t}-\mathrm{i}}^{2}+\sum_{\mathrm{j}=1}^{q} \beta_{\mathrm{j}} \sigma_{\mathrm{t}-\mathrm{i}}^{2}$

Burada $\omega>0, \quad \alpha 1 \geq 0$ ve $\beta 1 \geq 0$ olmalıdır. Ayrıca model negatif olmama kısıtı olarak adlandırılan $\sum_{i=1}^{q} \alpha_{i}+\sum_{j=1}^{q} \beta_{j}<1$

Kısıtını da sağlamalıdır (Ugurlu et. al, 2014). Aşağıda kurulan GARCH $(1,1)$ modelinin sonuçları görülmektedir. Görüldüğü gibi tüm katsayılar istatistiksel olarak anlamlıdır ve kısıtları sağlamaktadır.

Table 5: Estimated Coefficients of GARCH Models

\begin{tabular}{|c|c|c|}
\hline \multicolumn{3}{|c|}{ GARCH $(1,1)$} \\
\hline & Value & $p$ \\
\hline \multicolumn{3}{|c|}{ Ortalama Denklemi } \\
\hline C & 0.000714 & 0.0000 \\
\hline $\mathrm{AR}(5)$ & -0.745117 & 0.0000 \\
\hline MA(5) & 0.712951 & 0.0000 \\
\hline \multicolumn{3}{|c|}{ Varyans Denklemi } \\
\hline$C=\omega$ & $3.40 \mathrm{E}-06$ & 0.0000 \\
\hline $\operatorname{RESID}(-1)^{\wedge} 2=\alpha$ & 0.156355 & 0.0000 \\
\hline GARCH $(-1)=\beta$ & 0.808133 & 0.0000 \\
\hline \multicolumn{3}{|c|}{$\mathrm{GARCH}=\mathrm{C}(4)+\mathrm{C}(5)^{*} \mathrm{RESID}(-1)^{\wedge} 2+\mathrm{C}(6)^{*} \mathrm{GARCH}(-1)$} \\
\hline AIC & & -6.792857 \\
\hline SIC & & -6.777657 \\
\hline DW-stat & & 2.086299 \\
\hline \multicolumn{3}{|c|}{$\mathrm{N}=2259$} \\
\hline & Prob F & \\
\hline ARCH(1)LM Stat & 0.019689 & 0.8884 \\
\hline ARCH(2)LM Stat & 0.943891 & 0.3893 \\
\hline ARCH(3)LM Stat & 0.813159 & 0.4865 \\
\hline $\mathrm{ARCH}(4) \mathrm{LM}$ Stat & 0.778460 & 0.5391 \\
\hline ARCH(8)LM Stat & 0.546626 & 0.8218 \\
\hline ARCH(12)LM Stat & 0.839222 & 0.6098 \\
\hline $\mathrm{ARCH}(24) \mathrm{LM}$ Stat & 0.730939 & 0.8238 \\
\hline
\end{tabular}


Model kurulduktan sonra varyans modelinin ARCH etkisini giderip gidermediğinin anlaşılması için ARCH testleri yapılır. Testlerin sonucunda ARCH etkisinin ortadan kalktığı görülmüştür. Yukarıdaki denklemde $\omega>0, \alpha \geq 0, \beta \geq 0$ ve $\alpha+\beta<1$ olması durumunda GARCH $(1,1)$ zayıf durağan olarak anılır (Frimpong Joseph Magnus, 2008).

\section{SONUÇ}

$\mathrm{Bu}$ çalışmanın temel amacı Rassal Yürüyüş ve Etkin Piyasa Hipotezinin Standart \& Poors 500 endeksinde geçerliliğinin belli bir zaman serisi için test edilmesi olarak belirlenmiştir. Bu amacın yerine getirilebilmesi doğrultusunda, çalışmada S\&P 500 indeksindeki hisse senetlerinin 31-12-2009 ile 31-12-2018 tarihleri arasındaki günlük getiri verilerinden oluşan seri dikkate alınarak rassal yürüyüş ve etkin piyasa hipotezi test edilmiştir.

Etkin Piyasa Hipotezi bir yatırımcının finansal varlıklarından kazandığı getirinin bu yatırımcının aktif veya pasif bir yatırım yöneticisi olup olmadığı ile ilgisi olmadığını savunmaktadır. Etkin Piyasa Hipotezi finansal varlıkların fiyatının geçmiş fiyat endekslerine ve varlıklara ait olan diğer bilgiler üzerine yapılan çalışmalar aracılığı ile tahmin edilemeyeceğini savunmaktadır.

Etkin piyasanın varlığı ile ilgili tüm teoriler Fama gibi düşünmemekte, Fama'nın piyasa hipotezini eleştirmektedir. Örneğin, etkin piyasa hipotezi fiyatların öngörüsünde kullanılan teknik ve temel analiz yaklaşımlarını geçersiz sayar. Davranışsal finans alanında ise piyasalarda bazı anomaliler olduğunu tespit eden akademik çalışmalar etkin piyasalar hipotezi eleştirilmektedir. Anomaliler dönemsel, dönemsel olmayan ve teknik anomaliler olarak sınıflandırılmaktadır.

Etkin piyasa hipotezinin temeli rassal yürüyüş hipotezine dayanmaktadır. Böylelikle bu çalışma etkin piyasa hipotezini test ederken aynı zamanda da rassal yürüyüşün var olup olmadığını test etme özelliğine sahiptir. S\&P 500 endeksinde belirlenen zaman serisini oluşturan 31-12-2009 ile 31-12-2018 tarihleri arasındaki günlük kapanışlardan elde edilen getiri oranları dikkate alınarak serinin bir patern izleyip izlemediği araştırılmıştır.

Augmented Dickey-Fuller ve Phillips Perron Testi sonucuna göre araştırılan zaman serisinde birim kök tespit edilmemiş ve seri durağan bulunmuştur. ARMA testi uygulaması öncesi Korelogram çizileri dikkate alınarak model oluşturulmuştur.

Zaman serisi ARMA modeli ile test edilmiş ve AR değerlerin geçmişe bağımlı olduğu ve MA'nın gecikmeli hata terimlerinin şimdiki değerini etkilediği görülmektedir. ARMA modelinde ise AR (5) ve MA (5) katsayıları anlamlı çıkmış olup sonuçlar Rassal Yürüyüş hipotezini reddetmekte ve EPH ‘nin bu zaman serisi için geçerli olmadığı sonucunu vermektedir.

Modelin artıkları kullanılarak GARCH $(1,1)$ modeli kurulmuş ve tüm katsayılar istatistiksel olarak anlamlı bulunarak kısıtları sağladığı görülmektedir. Model kurulduktan sonra varyans modelinin ARCH etkisini giderip gidermediğinin anlaşılması için $\mathrm{ARCH}$ testleri tekrarlanmış ve sonucunda $\mathrm{ARCH}$ etkisinin ortadan kalktığı görülmüştür.

Çalışmanın temel kısıtı doğası gereği belli bir zaman serisini içermesi ve farklı zaman serilerinde farklı sonuçlar elde edilebilecek olmasıdır. Aynı zamanda çalışmanın sadece S\&P 500 endeksindeki veriler baz alarak yürütülmüş olması başka endekslere ait verilere de aynı sonuçların genellenebileceğini göstermediğinden bu durum da diğer bir kısıt olarak kabul edilebilir.

Müteakip çalışmalarda araştırmacıların farklı endekslerde etkin piyasa hipotezinin varlığını araştırmaları ve farklı zaman serilerinde araştırma yapmaları sonucun etkinliğini artıracaktır ayrıca farklı endeksler ve farklı zaman serileriyle yapılabilecek karşılaştırmalı çalışmaların da yapılabileceği değerlendirilmektedir. 


\section{KAYNAKLAR}

Agrawal A. and Tandon K. (1994). Anomalies of illusions? Evidence from stock markets in eighteen countries, Journal of International Money and Finance, 13, pp.83-106.

Aksu M.H. ve Önder T. (2003). The Size and Book-To-Market Effects and Their Role as Risk Proxies in the Istanbul Stock Exchange, Working Paper, EFMA 2000 Athens; Koc University, Gratuate School of Business, 2000-04, İstanbul.

Awad, I. and Daraghma Z. (2009). Testing the Weak-Form Efficiency of the Palestinian Securities, International Research Journal of Finance and Economics, Issue 32; pp.7-17.

Aydın N., Başar M. Ve Coşkun M. (2010). Finansal Yönetim, Detay Yayıncılık: Ankara.

Bachelier L. (1901). Theorie mathematique du jeu. Annales Scientifiques de l'Ecole Normale Superieure 18, pp.143-210.

Balaban, E. (1995). Informational Efficiency of the Istanbul Securities Exchange and Some Rationale for Public Regulation. The Central Bank of the Republic of Turkey, Discussion Paper No: 9502, pp.1-27.

Banz, R.W. (1981). The Relationship Between return and Market Value Of Common Stock, Journal of Financial Economics, 9(1).

Barnes P. (2016). Stock Market Efficiency Insider Dealing and Market Abuse, Routledge: London, pp.3-4.

Barone R. (2003). From Efficient Markets to Behavioral Finance, December 2003. University of Lecce Economics Working Paper No. 46/24.

Basu S. (1977). Investment Porformance of Common Stocks in Relation to Their Price-Earnings Ratios: A Test of the Efficient Market Hypothesis, The Journal of Finance, 32 (3), pp.663-682.

Bildik R. (2000). Hisse Senedi Piyasalarında Dönemsellikler ve İMKB Üzerine Ampirik Bir Çalışma, İMKB Yayınları, İstanbul.

Bircan H. ve Karagöz Y. (2003). Box-Jenkıns Modelleri ile Aylık Döviz Kuru Tahmini Üzerine Bir Uygulama, Kocaeli Üniversitesi Sosyal Bilimler Enstitüsü Dergisi (6) 2003/2, ss.49-62.

Bloomfield, Robert. Traditional vs. Behavioral Finance. Johnson School Research Paper Series, 2010, 222010.P.4. Available at: http://ssrn.com/abstract $=1596888$

Bollerslev, T. (1986) Generalized autoregressive conditional heteroskedasticity, Journal of Econometrics Volume 31, Issue 3, April 1986, Pages 307-327

Brav, Alon; HEATON, John B. Competing Theories of Financial Anomalies. Review of Financial Studies, 2002, 15 (2). p.575.

Brealey R.B., Myers S.C., Allen F. and Mohanty P. (2014). Principles of Corporate Finance, 11e. Mc Graw Hill.

Carnot N., Koen V. and Tissot B. (2005). Economic Forecasting. New York: Palgrave Macmillan.

Çevik E. İ. ve Erdoğan S. (2011). Bankacılık Sektörü Hisse Senedi Piyasasının Etkinliği: Yapısal Kırılma ve Güçlü Hafıza. Doğuş Üniversitesi Dergisi, 10 (1), ss.26-40.

Çinko M. (2008). İstanbul Menkul Kıymetler Borsasında Ocak Ayı Etkisi, Doğuş Üniversitesi Dergisi, 9 (1), ss.47-54.

Demireli E., Akkaya, G.C., İbaş E. (2010). Finansal Piyasa Etkinliği: S\&P 500 Üzerine Bir Uygulama, C.Ü. İktisadi Ve İdari Bilimler Dergisi, Cilt 11, Sayı 2.

Deng M. (2007). Death of the Efficient Market Hypothesis, 20th Australasian Finance \& Banking Conference 2007.

Dickey D.A. and Fuller W.A. (1979). Distribution of the Estimators for Autoregressive Time-Series with a Unit Root. Journal of the American Statistical Association, 74(366), pp. 427-431.

Eken M.H. ve Adalı S. (2008). Piyasa Etkinliği ve İMKB: Zayıf Formda Etkinliğe İlişkin Ekonometrik Bir Analiz, Mufad Journal, Sayı 37.

Enders W. (2014). Applied Econometric Time Series, Iowa State University, John Wiley\&Sons Inc. pp.239-240.

Fama F.E. (1965). “Random Walks in Stock Prices “, Financial Analyst Journal, Vol.21 , No 5. 
Fama F.E. (1970). Efficient capital markets: A review of theory and empirical work. The Journal of Finance, 25(2), pp.383-417.

Frimpong J.M. (2008).Capital Market Efficiency: An Analysis of Weak-form Efficiency on the Ghana Stock ExchangeJournal of Money, Investment and Banking ISSN 1450-288X Issue 5

Goodman D.A. and Peavy J.W. (1983). Industry Relative Price-Earning sRatio as Indicators of Investment Returns, Financial Analysis Journal. 39(4), pp.60-66.

Gujerati D. (2016). Örneklerle Ekonometri, 2. Edisyondan Çeviri. Palgraw Mc Millan, BB10. s.321.

Hanedar Ö. (2019) Durağanlık Analizi, Birim Kök Testleri ve Trend, http://debis.deu.edu.tr/userweb//onder.hanedar/dosyalar/Metin.pdf. Son erişim:12-01-2019

Harder S. (2008). The Efficient Market Hypothesis and Its Application to Stock Markets. Grin Verlag: Germany, p.5.

Harvey C.R. (1993). Predictable Risk And Returns in Emerging Markets, NBER Working Paper Series, Working Paper 4621.

Haugen R.A. ve Lakonishok J. (1988). The Incredible January Effect. Homewood: Dow Jones Irwin.

Hinich, M.J. and Patterson, D.M. (1995) Detecting epochs of transient dependence in white noise. Mimeo. University of Texas at Austin.

Jaffe J. and Westerfield R. (1985). The Week-End Effect in Common Stock Returns: The International Evidence, The Journal of Finance Vol. 40, No. 2 (June 1985), pp. 433-454.

Кантолинский, М. И. Аномалии Нафондовых Рынках: Определение И Классификация. Вестник, 2010, cтр. 26-27. URL: http://www.fa.ru/university/Documents/2-2010.pdf\#page=25

Kapetanios G., Shin, Y. and Snell, A. (2003) Testing For a Unit Root in the Nonlinear STAR Framework. Journal of Econometrics, Vol 112 (2), pp. 359-379.

Kartašova J. and Vicoskaitė I. (2013). Financial Market Anomalies: Efficient Market Non-existence Evidence KSI, Transactions on Knowledgesociety, Volume 6, Number 4, December 2013.

Kasman A. ve Kırkulak B. (2007). Türk Hisse Senedi Piyasası Etkin mi? Yapısal Kırılmalı Birim Kök Testlerinin Uygulanması. İktisat İşletme ve Finans, ss. 68-78.

Keim D.B. (1983). Size-related anomalies and stock return seasonality: Further empirical evidence. Journal of Financial Economics, Volume 12, Issue 1, June 1983, pp.13-32.

Kendall M.G. (1953). The Analysis of Economic Time series, Part 1. Prices, "Journal of the Royal Statistical Society 96, pp.11-25.

Kılıç Y. ve Buğan, M. F. (2016). The Efficient Market Hypothesis: Evidence from Turkey. International Journal of Academic Research in Business and Social Sciences, 6(10), 262-272.

Kıyılar M. ve Akkaya M. (2016). Davranışsal Finans. Literatür Yayıncılık, İstanbul, ss.64-65.

Kian-Ping L., Liew Sen V.K. and Wong Hock T. (2003). Weak-form Efficient Market Hypothesis, Behavioural Finance and Episodic Transient Dependencies: The Case of the Kuala Lumpur Stock Exchange, Finance 0312012, EconWPA; pp.2-26.

Kratz, Oliver S.(1999) Frontier Emerging Equity Markets Securities Price Behavior and Valuation, Kluwe Academic Publishers.America.S.20

Kruse R. (2011). A New Unit Root Test Against ESTAR Based On A Class of Modified Statistics. Statistical Papers, Vol 52 (1), pp. 71-85.

Kurt Cihangir Ç. ve Uğurlu E. (2017). Altın Piyasasında Asimetrik Oynaklık: Türkiye İçin Model Önerisi Sayfa 284-299 Journal of Business Research-Turk Cilt 9, Sayı 3. DOI: 10.20491/isarder.2017.300.

Ma, S., Barnes, M.L., 2001. Are China's stock markets really weak-form efficient? Discussion Paper No 0119, Adelaide University.

Malkiel, B.M (1994). Finance. Efficient Market Hypothesis. Edited by: Eatwell, J.,Milgate,M. \&Newman,P. Finance kitabı içerisinde. The Mac Millan Press Limited P.127

Özarı Ç. (2013). Ekonometri, Editör: Ömer Yılmaz ve Nihat Işık, Elma Basım: İstanbul. 
N. Komşuoğlu Yılmaz 11/3 (2019) 1559-1574

Peter C. B. and Phillips, Perron P. (1988). Testing for a Unit Root in Time Series Regression, Biometrika, Number: 75, pp. 335-346.

Samuelson, P. (1965) Proof That Properly Anticipated Prices Fluctuate Randomly. Industrial Management Review Spring, 6, 41-49.

Santos, Ana C. Behavioural and experimental economics: are they really transforming economics? Cambridge journal of economics, 2011, 35 (4): p. 706-707.

Shiguang M.A. and Barnes M.L. (2004). Are China's Stock Markets Really Weakform Efficient, CIES Discuission Paper No:119.

Smirlock M. and Starks L. (1986), Day-of-the-week and intraday effects in stock returns, Journal of Financial Economics, Volume 17, Issue 1, September 1986, pp.197-210.

Szyszka, Adam. From the Efficient Market Hypothesis to Behavioral Finance: How Investors' Psychology Changes the Vision of Financial Markets. November 17, 2007. Available at: http://ssrn.com/abstract=1266862

Taner T. ve Kayalıdere K. (2002). 1995-2000 Döneminde İMKB' de Anomali Araştırması, Yönetim ve Ekonomi, $9(1)$.

Thaler R., Russell T. (1987). The Relevance of Quasi-Rationality in Competitive Markets. American Economic Review. 77-3, pp.499-501.

Turaboğlu T.T. ve Topaloğlu T.N. (2017). Bir Etkin Piyasa Hipotezi Kavramı Olarak Anomaliler: Borsa İstanbul (BIST) Üzerinden Aylara İlişkin Anomalilere Yönelik Bir Araştırma, Ç.Ü. Sosyal Bilimler Enstitüsü Dergisi, Cilt 26, Sayı 1, ss.216-230.

Ugurlu E., Thalassinos E., Yusuf M., \& Ugurlu, E. (2014). Modeling Volatility in the Stock Markets using GARCH Models: European Emerging Economies and Turkey. International Journal in Economics and Business Administration, 72-87.

Uğurlu E., (2014). Modelling Volatility: Evidence form the Bucharest Stock Exchange. Journal of Applied Economic Sciences, 9 (4), pp. 718-726.

Yıldırım N. (2004). Firma Büyüklüğü ve Defter Değeri-Piyasa Değeri Etkileri: İMKB Örneği, İMKB Dergisi, 8 (31), ss.1-19.

Zeren F., Kara H. ve Arı A. (2013). Piyasa Etkinliği Hipotezi: İMKB İçin Ampirik Bir Analiz Dumlupınar Üniversitesi Sosyal Bilimler Dergisi, Sayı 36, Nisan 2013.

Zivot E. and Wang J. (2006). Modeling Financial Time Series with S-PLUS, Springer. s.127.

www.myistatistik.com/metodoloji/birim-kok/ Son erişim:12-01-2019

http://www.real-statistics.com/time-series-analysis/stochastic-processes/dickey-fuller-test/. Son erişim:12-012019 